\section{Obama demands rethink of regulatory processes}

President Barack Obama is changing the way that the US government sets its regulations. The move is one of a series of actions that will affect science-informed rules from pollution standards to food-safety inspections.

Obama has asked Peter Orszag, the new head of the Office of Management and Budget $(\mathrm{OMB})$, to suggest revisions to the office's fundamental principles for reviewing proposed government regulations. He has also revoked an executive order, signed in January 2007 by notoriously regulation-averse former President Bush, that had allowed a political appointee in each agency to veto proposed regulations before they became public.

Rick Melberth, head of regulatory policy at the Washington DC group OMB Watch, says that analysts there are "very happy" with Obama's early steps to reform. Many of the problems, he says, predate the Bush administration. "For three decades, there have been an increasing number of obstacles placed in the way of agencies being able to regulate in a timely and effective manner.'

\section{US takes pole position in generation of wind power}

The United States has surpassed Germany as the world's largest wind-power producer, according to statistics released by the Global Wind Energy Council earlier this month.

Despite many projects being delayed owing to the economic crunch last autumn, wind producers around the world installed more than 27 gigawatts of capacity in 2008, bringing global capacity to nearly 121 gigawatts (see chart). The United States led the way with 8.4 gigawatts of new capacity, to reach nearly 25.2 gigawatts in total. Wind turbines provided about $42 \%$ of the nation's new power-producing capacity in 2008.

Collectively, Europe added 8.9 gigawatts, bringing its total to 66 gigawatts. China more than doubled its capacity, reaching 12.2 gigawatts, and industry officials say

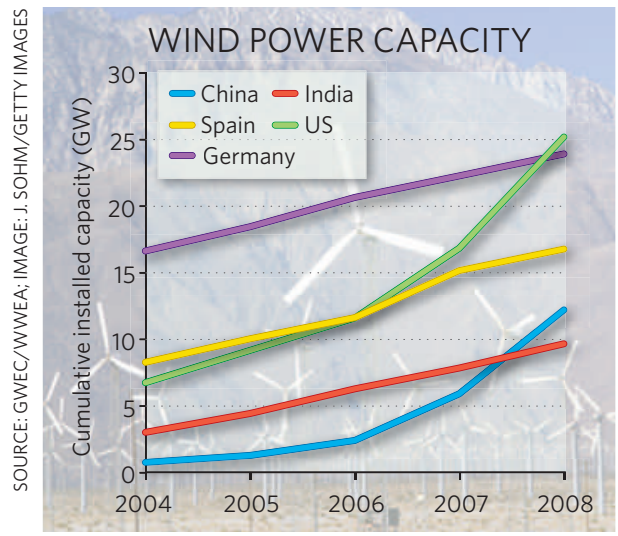

\title{
Lucy's museum tour threatens to become a spell in storage
}

The 3.2-million-year-old bones of 'Lucy' (pictured), the skeleton of the Australopithecus afarensis hominin discovered in Ethiopia in 1974, have undergone a complete high-resolution computed tomography scan. Researchers at the University of Texas at Austin have thereby created a digitized record that will allow the bones' internal structure to be examined (inset). But interest from US museums in hosting an exhibition featuring the $40 \%$ complete skeleton is lagging, and officials say it will go into indefinite storage next month at the Houston Museum of Natural Science in Texas.

A \$2.25-million, five-month Lucy exhibition at the Pacific Science Center in Seattle, Washington, which closes on 8 March, is the second leg of what was originally planned to be a ten-city, six-year tour, although concerns were raised over the effects the tour would have on the delicate fossil (see Nature 444, 8; 2006). But total attendance at the Seattle exhibition is likely to be a third of the 250,000 projected, and no other museum has yet signed up for the exhibition.
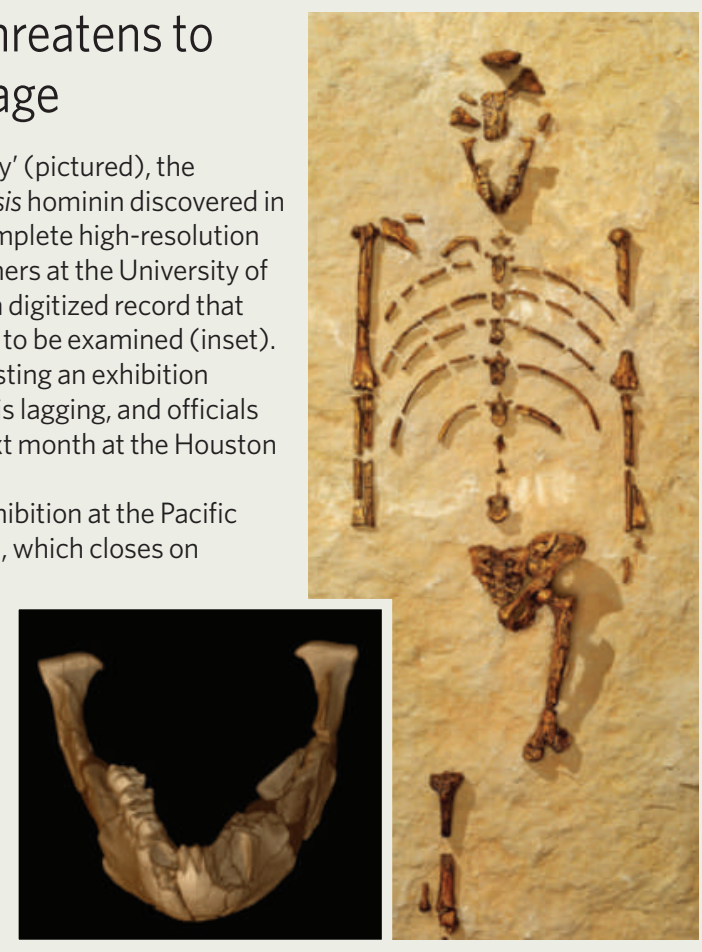

that they expect the country's capacity to double again this year.

The council estimates that the industry now employs some 400,000 people, with the 2008 market for new turbines and installations ringing in at $\$ 47.5$ billion.

\section{Pakistan releases nuclear smuggler from house arrest}

Abdul Qadeer Khan, the father of Pakistan's nuclear bomb and a central figure in a major nuclear smuggling ring, has been freed.

A brief order issued on 6 February by the Islamabad High Court released the 72-year-old metallurgist from house arrest. Khan had been confined since 2004, after confessing to selling Pakistani nuclear technology to Iran, North Korea and Libya. The government had pardoned him after his admission but kept him under strict guard in his Islamabad home.

Khan's visitors and phone calls will be monitored by the Pakistani Interior Ministry and he will not be allowed to leave the country.

\section{Sweden backs construction of new nuclear plants}

The Swedish government has overturned its almost 30-year-old ban on the construction of nuclear power plants.

The moratorium, which dates back to 1980 , committed the government to shutting existing plants and banned the building of new ones. Ten reactors still supply the country with nearly half of its electricity.

The new policy, announced by the coalition government on 5 February, annuls the phase-out and allows for the construction of replacements for the ten existing reactors. The government thinks that nuclear power stations will be needed to meet the nation's goal of no net greenhouse-gas emissions by 2050 .

Sweden is the second European nation to reverse its nuclear policy in the past year. In May 2008, Italy announced it planned to resume building new nuclear power plants.

\section{Transgenic drug gets green light from the United States}

The US Food and Drug Administration (FDA) has issued its first approval of a drug produced by a genetically engineered animal.

The drug, marketed as ATryn, is the human blood protein antithrombin and will be used to treat various bloodclotting disorders. It is produced in the milk of transgenic goats engineered by GTC Biotherapeutics, a company based in Framingham, Massachusetts.

The FDA's decision, released on 6 February, had been delayed while the agency worked out how to regulate products made from genetically engineered animals. It finally issued industry guidelines on 15 January this year (see Nature 457, 371; 2009), and it was widely expected that approval of ATryn, which had already been given the green light by a scientific advisory committee, would soon follow. The drug was approved in Europe in June 2006. 